\title{
Funding Innovation Thanks to Anti-TNF- $\alpha$ Biosimilars Uptake: The Economic Impact in Italy
}

Massimiliano Povero ${ }^{1}$, Lorenzo Pradelli ${ }^{1}$

${ }^{1}$ AdRes HE\&OR, Turin, Italy

\begin{abstract}
INTRODUCTION: Anti-TNF- $\alpha$ biosimilars (ATB) hold the promise of reducing costs leading in improving access to biological therapies. There is limited insight into how the savings generated by biosimilars may translate into patient benefit in other disease areas.

AIMS: To assess the economic savings for Italian National Health System (NHS) due to the expansion of ATB market, together with a reduction in their price and to illustrate how this potential savings can be used by NHS to fund orphan drugs. METHODS: Trend of IMS Health monthly sell-in units (August 2016-December 2019) were used to estimate the current biologic and biosimilar market for rheumatic and inflammatory bowel disease in Italy and its evolution up to 2022 . The scenario for 2019-2020 was compared with the future evolution (2021-2022) assuming an increasing uptake of biosimilars in the Italian market. Finally, it was estimated how these savings can potentially fund the treatment of orphan drugs, without increasing the Italian NHS budget.

RESULTS: Italian biologic and biosimilar market remains stable in the next years (about 4 million units both in the current scenario and in the future evolution market) with a slight decreasing of less than $2 \%$. However, according to our assumptions, ATB market is expected to increase of about $33 \%$ in the next two years, covering $67 \%$ of the total Italian market, mostly due to biosimilar etanercept. Total savings due to biosimilars increases from $€ 96$ million in 2019 to $€ 161$ million in 2022 corresponding to a mean annual savings of about $€ 130$ million. Such savings would permit funding $17.4 \%$ of the actual orphan drugs market corresponding to 2,600-4,800 new patients.

CONCLUSIONS: The introduction of biosimilars in a range of rheumatic, dermatological and inflammatory bowel disease can be an opportunity to increase patient access to innovative treatments. Potential savings due to biosimilars uptake could lead to a re-allocation of economic resources to fund innovative therapies.
\end{abstract}

\section{Keywords}

Anti-TNF- $\alpha$; Biosimilar; Savings; Funding innovation; Orphan drugs

\section{INTRODUCTION}

According to the European Medicines Agency (EMA), a biosimilar drug is a version of an already registered original product, the reference product (RP), whose qualitative characteristics, biological activity, and safety and efficacy profiles have been shown to be similar to those of the RP by means of comparability studies [1]. The first-generation biologics were launched in the early 1980s, and this innovative class of drugs is now one of the fastest growing sectors of the pharmaceutical industry [2].

Biosimilars and reference drugs cannot be considered to be totally equivalent since, even after patent expiration, the reference agent manufacturer is not obliged to reveal details of its production practice [3]. Furthermore, biologicals are produced using living cells that have inherent variability, hence they are complex mixtures of closely related molecules that cannot be copied exactly. Similarity to the RP is demonstrated in a comprehensive biosimilarity exercise including comparative physicochemical characterization, biological activity assessment, pharmacokinetic studies and clinical trials. A biosimilar may be approved by the EMA based on clinical data in a sensitive indication; efficacy and safety data may be extrapolated to other indications approved for the RP, meaning that a biosimilar agent may not have been clinically tested in each indication $[1,4]$.

The EMA's assessment of biosimilar medicines is done exclusively for the purpose of marketing authorization; Any decision to transition a patient from RP to biosimilar should

Corresponding author Massimiliano Povero m.povero@adreshe.com

Received: 24 October 2019 Accepted: 20 March 2020 Published: 7 May 2020 
be made by qualified healthcare personnel on the basis of national or local guidelines [5]. The Italian Medicines Agency (Agenzia Italiana del Farmaco, AIFA) considers biosimilars and RP as interchangeable products (i.e. they are assumed to have the same effectiveness and they can be used for the same disease), both for naïve patients and for patients already under treatment, but recommends that the decision to prescribe a biosimilar drug be made exclusively by the specialist managing the specific disease [6]. Clinicians must thus be aware of the availability of a biosimilar and they must be free to make informed treatment choices with their patients.

As of the end of 2019, there are ten approved anti-TNF- $\alpha$ biosimilar (ATB) medicines that are available on the Italian market. Three biosimilar versions of infliximab, one of which is available under two brand names, Inflectra ${ }^{\circledR}$ and Remsima ${ }^{\circledR}$ (manufactured by Celltrion Inc.), one under the brand name Flixabi ${ }^{\circledR}$ (manufactured by Biogen), and one under the brand name Zessly ${ }^{\circledR}$ (manufactured by Sandoz). All biosimilars are approved for use in rheumatoid arthritis (RA), adult and pediatric Crohn's disease (CD), adult and pediatric ulcerative colitis (UC), ankylosing spondylitis (AS), psoriatic arthritis (PsA), and psoriasis [7-9]. Two etanercept biosimilars are available under the brand name Benepali ${ }^{\circledR}$ (manufactured by Biogen) and Erelzi ${ }^{\circledR}$ (manufactured by Sandoz). Both biosimilars are approved for the treatment of adults with RA, PsA, axial spondyloarthritis (AS and non-radiographic axial spondyloarthritis), juvenile idiopathic arthritis (JIA), and plaque psoriasis including pediatric in patients weighing $>62.5 \mathrm{~kg}[10,11]$. Finally, five adalimumab biosimilars have been approved in Europe for use in mostly the same indications as reference adalimumab including rheumatology, gastroenterology and dermatology: Amgevita ${ }^{\circledR}$ (Amgen), Imraldi ${ }^{\circledR}$ (Biogen), Hyrimoz ${ }^{\circledR}$ (Sandoz), Hulio ${ }^{\circledR}$ (Mylan) and Idacio $^{\circledR}$ (Fresenius Kabi). Amgevita ${ }^{\circledR}$ and Imraldi ${ }^{\circledR}$ are reimbursed in Italy since the end of 2018, Hyrimoz and Hulio during 2019, while Idacio has not yet been reimbursed [12-16].

Switching between a RP and a ATB is relevant for clinical practice, but also for pharmacoeconomic considerations; the arrival of ATB is expected to provide cost savings and expand access to other medicinal products [17]. While there is continued debate about interchangeability of biosimilars, recent systematic reviews concluded that there was no increased risk of immunogenicity or adverse events, and no significant loss of efficacy or effectiveness was observed [18-21]. According to another comprehensive systematic review of published evidence summarizing all of the available studies (up to September 2015) on biosimilars across multiple therapeutic areas and at all stages of development [22], both Inflectra ${ }^{\circledR}$ and Flixabi ${ }^{\circledR}$ are reported to have shown evidence of similarity with their originator, based on results of clinical studies as well as a large number of patients described in real-world studies.

The NOR-SWITCH study [23], involved 481 adult patients with a diagnosis of RA, AS, PsA, CD, UC or plaque psoriasis, on stable treatment with the originator infliximab (Remicade $^{\circledR}$ ) for at least 6 months prior to randomization; patients were randomized to continue RP, or switch to CT-P13 (Inflectra ${ }^{\circledR} /$ Remsima $^{\circledR}$ ) and followed for 52 weeks, clinical outcomes were comparable between the two arms. Furthermore real-word studies [24,25] and results from PLANETAS and PLANETRA extension studies [26,27], showed analogous results for infliximab biosimilars for patients with RA and AS.

In an open-label extension to the phase III, 52-week randomized study that compared etanercept biosimilar SB4 (Benepali ${ }^{\circledR}$ ) with reference etanercept $\left(\right.$ Enbrel $\left.^{\circledR}\right)$ for the treatment of RA, 126 patients continued to receive ATB and 119 patients switched from reference etanercept to SB4 for a further 48 weeks [28]. At the end of this open-label treatment period, the efficacy, safety and immunogenicity profiles were comparable for both groups. A real-world study, evaluating the safety and effectiveness of switching from Enbrel ${ }^{\circledR}$ to Benepali ${ }^{\circledR}$ in patients with RA, PsA or axial spondyloarthritis [29] reported no clinically relevant difference in disease activity at 3 months post-switch, nor in that observed in the 3 months prior to switch.

Inotai et al. [30] conducted a systematic literature review to assess the clinical consequences of switching from originator biologics to biosimilar. The analysis identified 58 papers: 41 non-empirical papers (15 not disease specific, 9 on IBD, 5 on RA, 5 on chronic kidney disease and anemia, and 3 focused on malignancies), 5 systematic reviews ( 3 on infliximab and related ATB in inflammatory diseases, and 2 no drug-specific) and 12 original clinical studies ( 4 on IBD, 4 on chronic kidney disease and anemia, 2 on RA, and 1 on AS). None of the 5 systematic reviews concluded that there were safety or efficacy concerns in switching from the original biologics to biosimilars, and 3 of them also explicitly stated that switching from an original biologic to a biosimilar drug was not associated with increased safety risk, while effectiveness was maintained. Also, two trials explicitly reported no adverse events or loss of efficacy related to switching, whereas 10 trials concluded that, overall, there was no increased 
risk of immunogenicity or adverse events, while no statistically significant loss of efficacy was observed. In conclusion, the opinion of the authors of this review is that the fear against switching to biosimilars is not supported by empirical evidence.

The last position paper on ATB published in Italy by AIFA [6], confirmed this statement and highlighted the importance of ATB in improving the accessibility to biological therapies due to high cost of RP. Use of biosimilars in the EU5 countries alone stands to offer savings of more than $€ 10$ billion between 2016 and 2020 [31]. Expanding ATB market could finance other therapeutic area, partially or completely.

Aims of this paper are

- To assess the economic savings for Italian National Health System (NHS) due to the expansion of ATB market, together with a reduction in their price,

- To illustrate how this potential savings can be used by NHS to fund orphan drugs.

\section{METHODS}

The anti-TNF- $\alpha$ market evolution in Italy was estimated using monthly sell-in units between January to December 2019 [32], applying an annual increasing rate estimated from August 2018 to December 2019 and supposed constant up to 2022 (Table I). Only formulations available both as RP and ATB were considered in the analysis, e.g. Enbrel ${ }^{\circledR}$ (etanercept) 10 $\mathrm{mg}$ is excluded from the analysis since not available as biosimilar. Annual ATB uptake was assumed almost linear from 2019 to 2022 for all treatments considered in the analysis according to Biogen internal analysis (Figure 1). Current market was defined as biennium 2019-2020, future market as biennium 2021-2022.

Only drug acquisition cost was considered in the analysis since, as described in the introduction, no evidence of lower efficacy or increased toxicity with or after switching to an ATB were detected in clinical trials or real-world studies. The ex-factory reimbursement price [33] charged to NHS, net of price reductions stipulated by law and by tender procedures [34] was considered for all available products (Table II).

\begin{tabular}{lcc}
\hline \multicolumn{1}{c}{ RP/ATB } & Actual Market (2019 sell-in units) & Annual increasing (2020-2022) \\
\hline Adalimumab (40 mg syringes/pens) & 734,853 & $+7.1 \%$ \\
Etanercept (25 mg syringes/pens) & 114,687 & $-4.3 \%$ \\
Etanercept (50 mg syringes/pens) & 812,085 & $-9.1 \%$ \\
Infliximab (100 mg vials) & 277,489 & $-2.5 \%$ \\
\hline
\end{tabular}

Table I. Italian biologic and ATB market for 2019 (number of unit sold between January and December) and 2020-2022 evolution ATB $=$ anti-TNF- $\alpha$ biosimilars; RP $=$ reference products

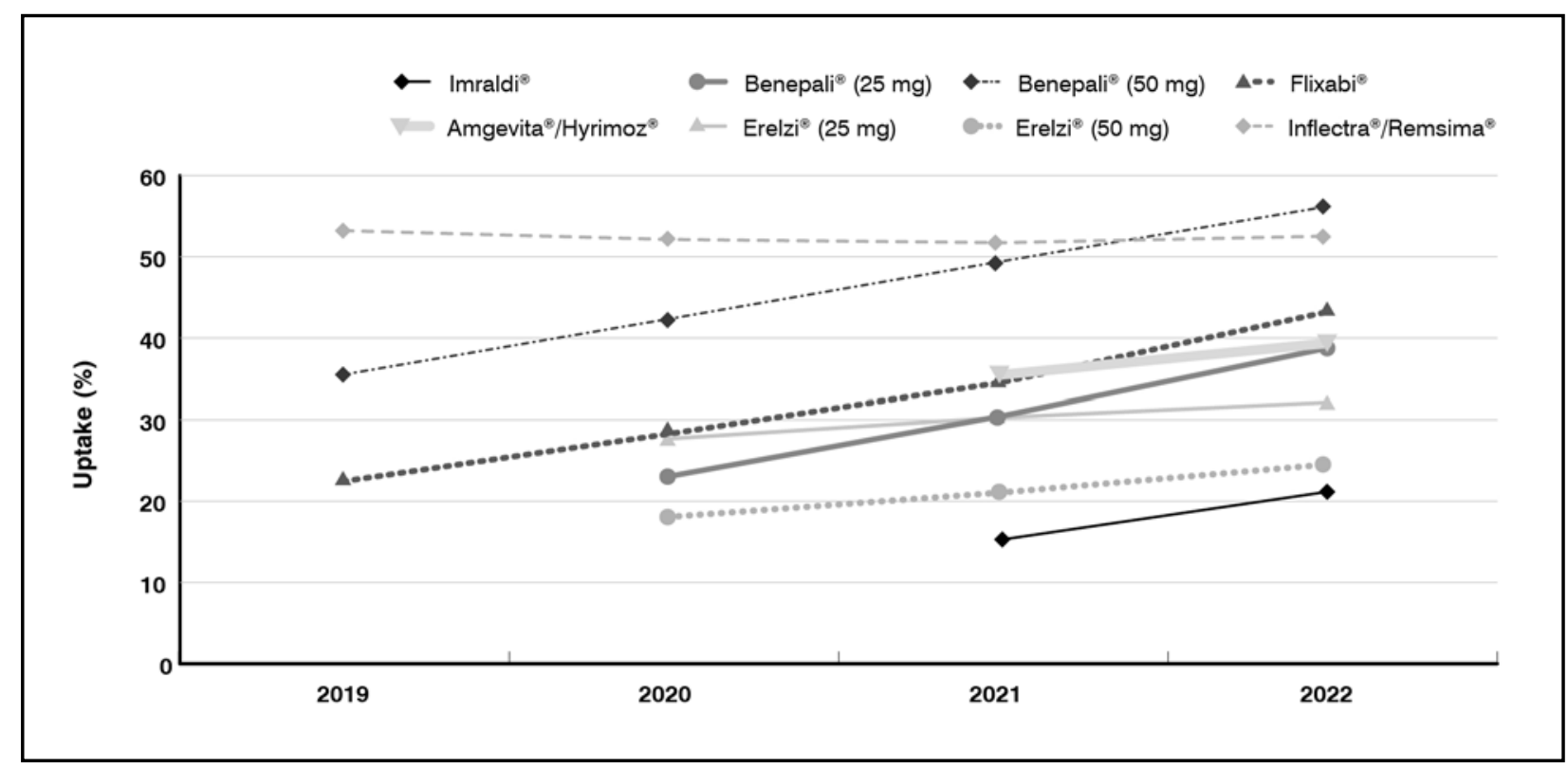

Figure 1. Italian anti-TNF- $\alpha$ biosimilars uptake for 2019-2022 


\begin{tabular}{|c|c|c|c|}
\hline Drug & Branded & Pharmaceutical form & Ex-factory price $(€)$ \\
\hline \multirow[t]{4}{*}{ Adalimumab } & Humira ${ }^{\circledR}$ & $40 \mathrm{mg}$ solution for injection in pre-filled syringe & 482.19 \\
\hline & Imraldi ${ }^{\circledast}$ & & 342,35 \\
\hline & Amgevita $^{\circledR}$ & & 342,35 \\
\hline & Hyrimoz $^{\circledR}$ & & 342,35 \\
\hline \multirow[t]{6}{*}{ Etanercept } & Enbrel $^{\circledR}$ & $25 \mathrm{mg}$ solution for injection in pre-filled syringe & 115.13 \\
\hline & & $50 \mathrm{mg}$ solution for injection in pre-filled syringe & 230.26 \\
\hline & Benepali $^{\circledR}$ & 25 mg solution for injection in pre-filled syringe & 78.52 \\
\hline & & $50 \mathrm{mg}$ solution for injection in pre-filled syringe & 157.25 \\
\hline & Erelzi ${ }^{\circledR}$ & $25 \mathrm{mg}$ solution for injection in pre-filled syringe & 74.84 \\
\hline & & $50 \mathrm{mg}$ solution for injection in pre-filled syringe & 149.67 \\
\hline \multirow[t]{5}{*}{ Infliximab } & Remicade $^{\circledR}$ & 100 mg powder for concentrate for solution for infusion & 463.53 \\
\hline & Flixabi $^{\circledR}$ & & 386.28 \\
\hline & Inflectra ${ }^{\circledR}$ & & 386.28 \\
\hline & Remsima $^{\circledR}$ & & 386.28 \\
\hline & Zessly ${ }^{\circledR}$ & & 386.28 \\
\hline
\end{tabular}

Table II. Ex-factory prices in Italy

The savings generated by all ATB available in the Italian market was calculated as the difference between the actual market (Table I) and the hypothetical market with all ATB replaced by the corresponding RP. Finally, a simulation estimated how these savings can potentially fund innovative treatments for orphan diseases.

The current model of attribution of the degree of innovation defined by AIFA [35] is based on three domains: the therapeutic need (TN), the added therapeutic value (ATV), and the quality of the evidence (QE) carried to support the drug. The first two factors are graded in five levels (maximum, important, moderate, poor, absent), the third factor is evaluated as high, moderate, low, very low. A drug is declared innovative if QE is "high" and both TN and ATV are valued "maximum" or "important". For rare diseases, a greater difficulty in conducting clinical trials is acknowledged, which is why is it possible to consider innovative a drug with low QE, provided TN and ATV are high [35].

All orphan drugs, that were granted the innovative status up to end of January 2019 [36] were included in the analysis (Table III).

The economic impact of each drug was calculated by estimating the annual number of new patients that should be treated with each drug and the cost of the first year of treatment [37-49]. According to the savings produced by ATB uptake, a percentage of this impact could be funded, i.e. a fraction of patients could be treated without increasing the NHS budget. Two potential allocation algorithms, depending on the policy preferred by the decision-makers, were considered:

- Cost allocation proportional to number of potential new patients; i.e. the higher the disease incidence, the higher the fraction of resources dedicated to that disease;

- Optimal allocation calculated in order to globally maximize the fraction of patients (across diseases) potentially treated without increasing NHS expenditures.

\section{RESULTS}

Evolution of the Italian biologic and biosimilar market due to increasing use of ATB is illustrated in Figure 2. Italian market remains basically stable in the next years: 3.85 million units in the current market (2019-2020) compared with 3.80 million in the future evolution market (2021-2022), corresponding to a slight decreasing of about 1.4\% (Table IV). However, according to our assumptions, ATB market is expected to increase of $33 \%$ up to 2022 , covering $67 \%$ of the total Italian market, mostly due to adalimumab (38\%) and etanercept (44\%) biosimilars uptake.

The economic impact of ATB uptake in Italy is detailed in Table V. Total savings due to ATB increases from $€ 96.2$ million in 2019 to $€ 161.5$ million in 2022 (mean annual savings $€ 128.8$ million). Comparing 2019-2020 market with future evolution in the total savings amount to about $€ 84$ million.

The number of new patients potentially treated for selected orphan diseases ranges between 15 for autologous CD34+ cells to almost 9,700 for cenegermin in Italy (Table VI). 


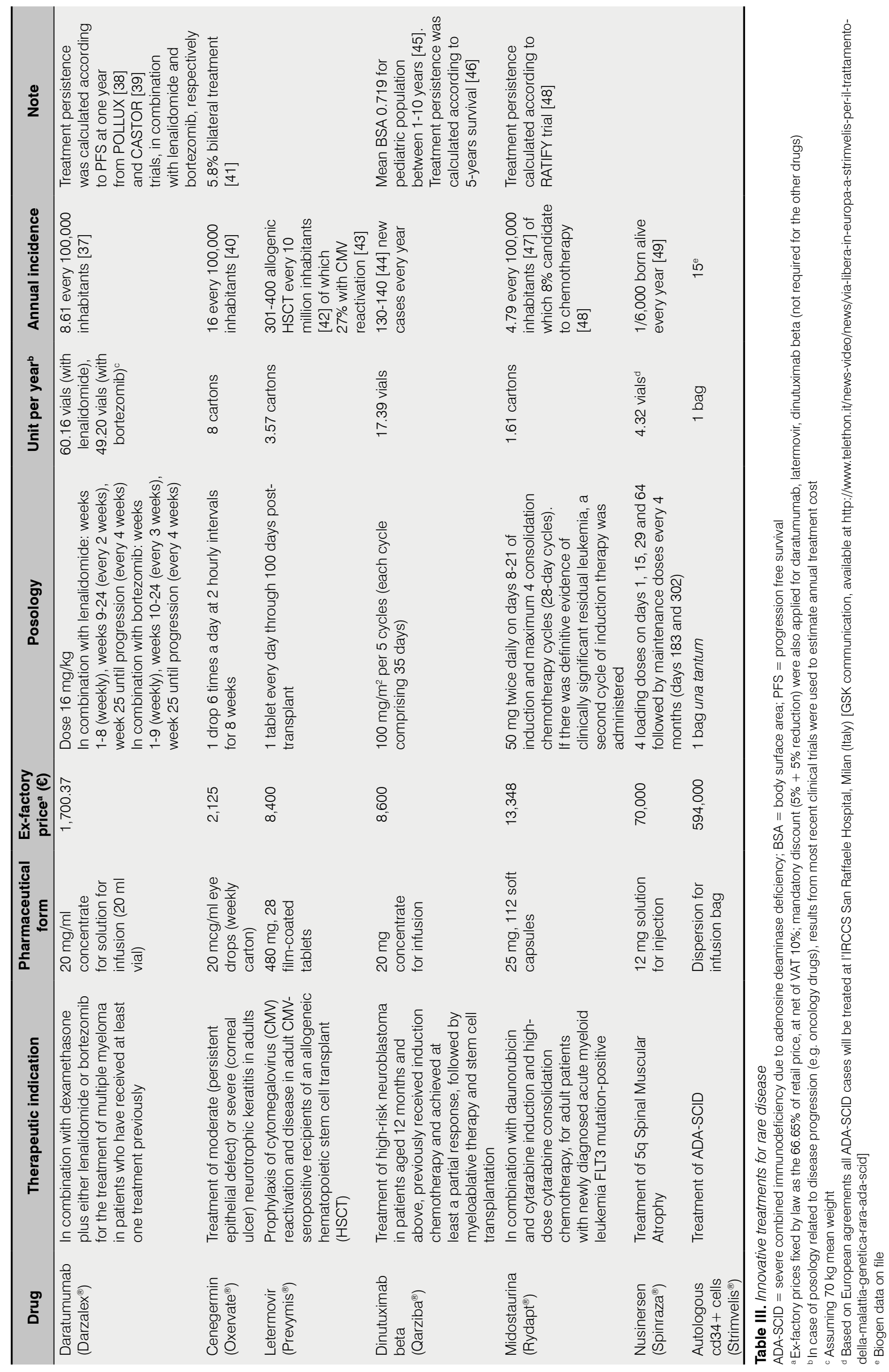




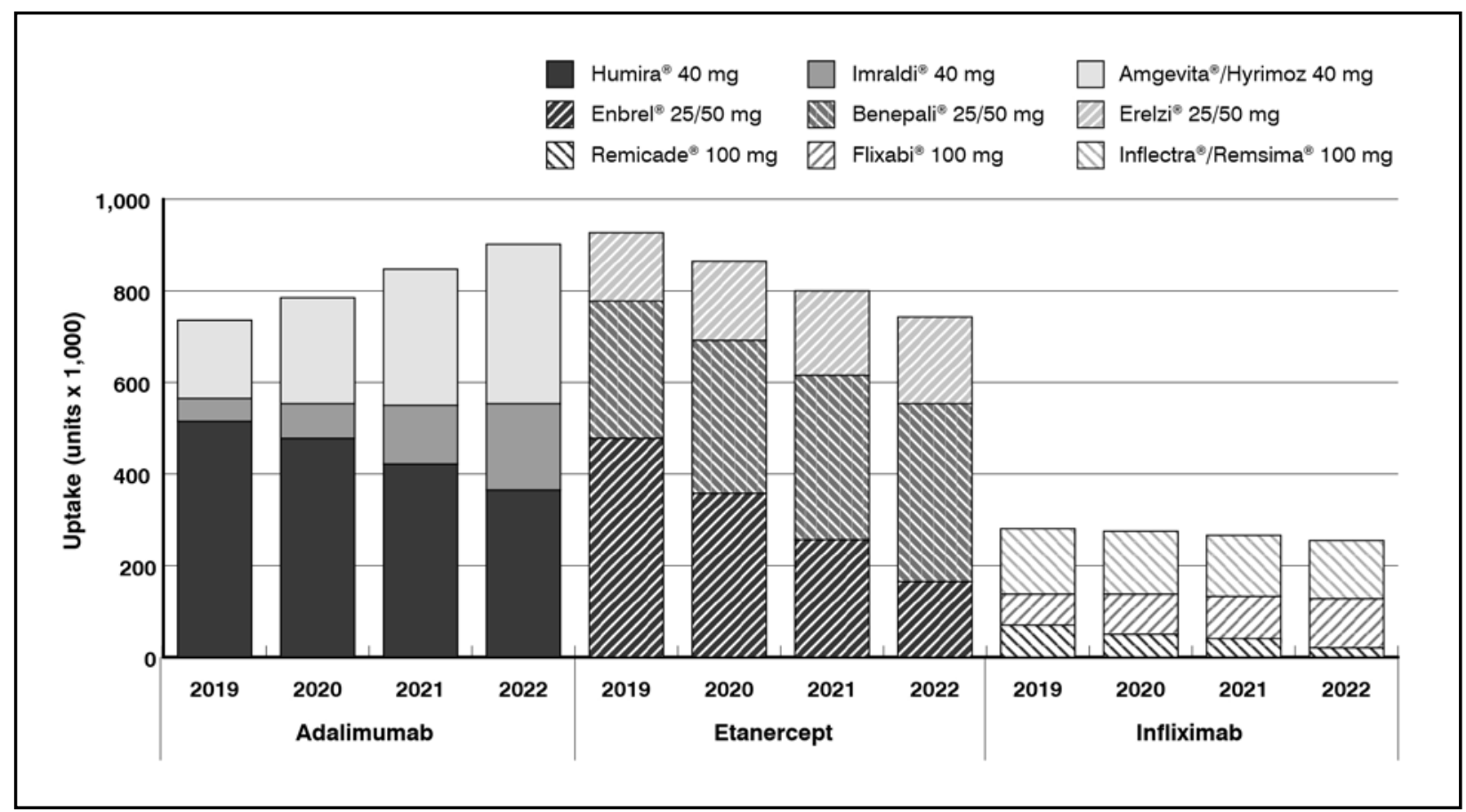

Figure 2. Resulting Italian market for 2019-2022

\begin{tabular}{lcc}
\hline & $\mathbf{2 0 1 9 - 2 0 2 0}$ & $\mathbf{2 0 2 1 - 2 0 2 2}$ \\
\hline Italian market (total biologic and biosimilar sell-in units) & $3,854,311$ & $3,801,377$ \\
ATB market, units (\%) & $1,914,379(50 \%)$ & $2,554,607(67 \%)$ \\
Adalimumab, units (\%) & $535,192(28 \%)$ & $962,521(38 \%)$ \\
Etanercept, units (\%) & $954,678(50 \%)$ & $1,123,802(44 \%)$ \\
Infliximab, units (\%) & $424,509(22 \%)$ & $468,284(18 \%)$ \\
\hline
\end{tabular}

Table IV. Comparison between 2019-2020 Italian market and evolution estimated for 2021-2022 ATB $=$ anti-TNF- $\alpha$ biosimilars

\begin{tabular}{lcc|cc}
\hline & \multicolumn{2}{c}{ Current market } & Future market evolution \\
\cline { 2 - 5 } & $\mathbf{2 0 1 9}$ & $\mathbf{2 0 2 0}$ & $\mathbf{2 0 2 1}$ & $\mathbf{2 0 2 2}$ \\
\hline Annual drug cost - market without ATB $(€)$ & $612,683,002$ & $617,038,368$ & $624,426,997$ & $634,832,963$ \\
Annual drug cost - market with ATB $(€)$ & $516,465,296$ & $497,648,431$ & $486,202,672$ & $473,365,303$ \\
Savings due to ATB $(€)$ & $96,217,706$ & $119,389,937$ & $138,224,325$ & $161,467,660$ \\
Mean annual saving due to ATB $(€)$ & & \multicolumn{2}{c}{$128,824,907$} \\
Increase in total savings due to ATB - future vs current market $(€)$ & & \multicolumn{2}{c}{$84,084,342$} \\
\hline
\end{tabular}

Table V. Economic impact of ATB market increasing in Italy ATB: anti-TNF- $\alpha$ biosimilars

Different allocation strategies gave different consequences on the number of patients treated without impacting NHS expenditures: with strategy 1 (cost allocation proportional to disease incidence), 4,837 new patients can be funded by ATB saving where the proportions of patients treated for each disease result very different (Table VI and Figure 3); with strategy 2 (optimal allocation) instead, the fraction of patients treated without impacting NHS results around 14$18 \%$, but the total number of patients decreases down to 2,640 (Table VI and Figure 3).

\section{DISCUSSION}

In this analysis we estimated the total pharmaceutical impact of ATB in the 2019 Italian market and its evolution in the next three years due to increasing ATB. Biosimilars market 


\begin{tabular}{|c|c|c|c|c|c|c|}
\hline \multirow[b]{2}{*}{ Drug } & \multirow{2}{*}{$\begin{array}{c}\text { New } \\
\text { patients } \\
\text { (n/year) }\end{array}$} & \multirow{2}{*}{$\begin{array}{l}\text { Therapy } \\
\text { cost } \\
\text { (€/year) }\end{array}$} & \multicolumn{2}{|c|}{$\begin{array}{l}\text { Strategy 1: Cost allocation } \\
\text { proportional to disease incidence }\end{array}$} & \multicolumn{2}{|c|}{$\begin{array}{l}\text { Strategy 2: Optimal } \\
\quad \text { allocation }^{\mathrm{a}}\end{array}$} \\
\hline & & & $\begin{array}{l}\text { Savings } \\
\text { allocation (\%) }\end{array}$ & $\begin{array}{c}\text { New patients } \\
\text { potentially } \\
\text { treated }(\mathrm{n})\end{array}$ & $\begin{array}{c}\text { Savings } \\
\text { allocation } \\
(\%) \\
\end{array}$ & $\begin{array}{c}\text { New patients } \\
\text { potentially } \\
\text { treated }(\mathrm{n})\end{array}$ \\
\hline Daratumumab (Darzalex $\left.{ }^{\circledR}\right)$ & 5,197 & 92,982 & 32.7 & 453 & 69.2 & 959 \\
\hline Cenegermin $\left(\right.$ Oxervate $\left.^{\circledR}\right)$ & 9,658 & 18,957 & 60.8 & 4,132 & 22.5 & 1,532 \\
\hline Letermovir (Prevymis ${ }^{\circledR}$ ) & 574 & 30,000 & 3.6 & 155 & 1.9 & 83 \\
\hline Dinutuximab beta $\left(\right.$ Qarziba $\left.{ }^{\circledR}\right)$ & 135 & 149,515 & 0.8 & 7 & 2.3 & 20 \\
\hline Midostaurina (Rydapt ${ }^{\circledR}$ ) & 231 & 21,485 & 1.5 & 87 & 0.6 & 33 \\
\hline Nusinersen $\left(\right.$ Spinraza $\left.{ }^{\circledR}\right)$ & 73 & 302,400 & 0.5 & 2 & 2.5 & 11 \\
\hline $\begin{array}{l}\text { Autologous cd34 + cells } \\
\left(\text { (Strimvelis }^{\circledR}\right)\end{array}$ & 15 & 594,000 & 0.1 & $<1$ & 1.0 & 2 \\
\hline Total & 15,883 & $739,677,228$ & 100 & 4,837 & 100 & 2,640 \\
\hline $\begin{array}{l}\text { Mean annual savings } \\
\text { due to ATB (€/year) }\end{array}$ & \multicolumn{6}{|c|}{$128,824,907$} \\
\hline
\end{tabular}

Table VI. New patients potentially treated without impact on NHS due to ATB savings ${ }^{a}$ Optimal allocation was defined as the resources allocation that permits to fund the maximal percentage of patients globally (i.e. for all diseases considered in the analysis) ATB $=$ anti-TNF- $\alpha$ biosimilars

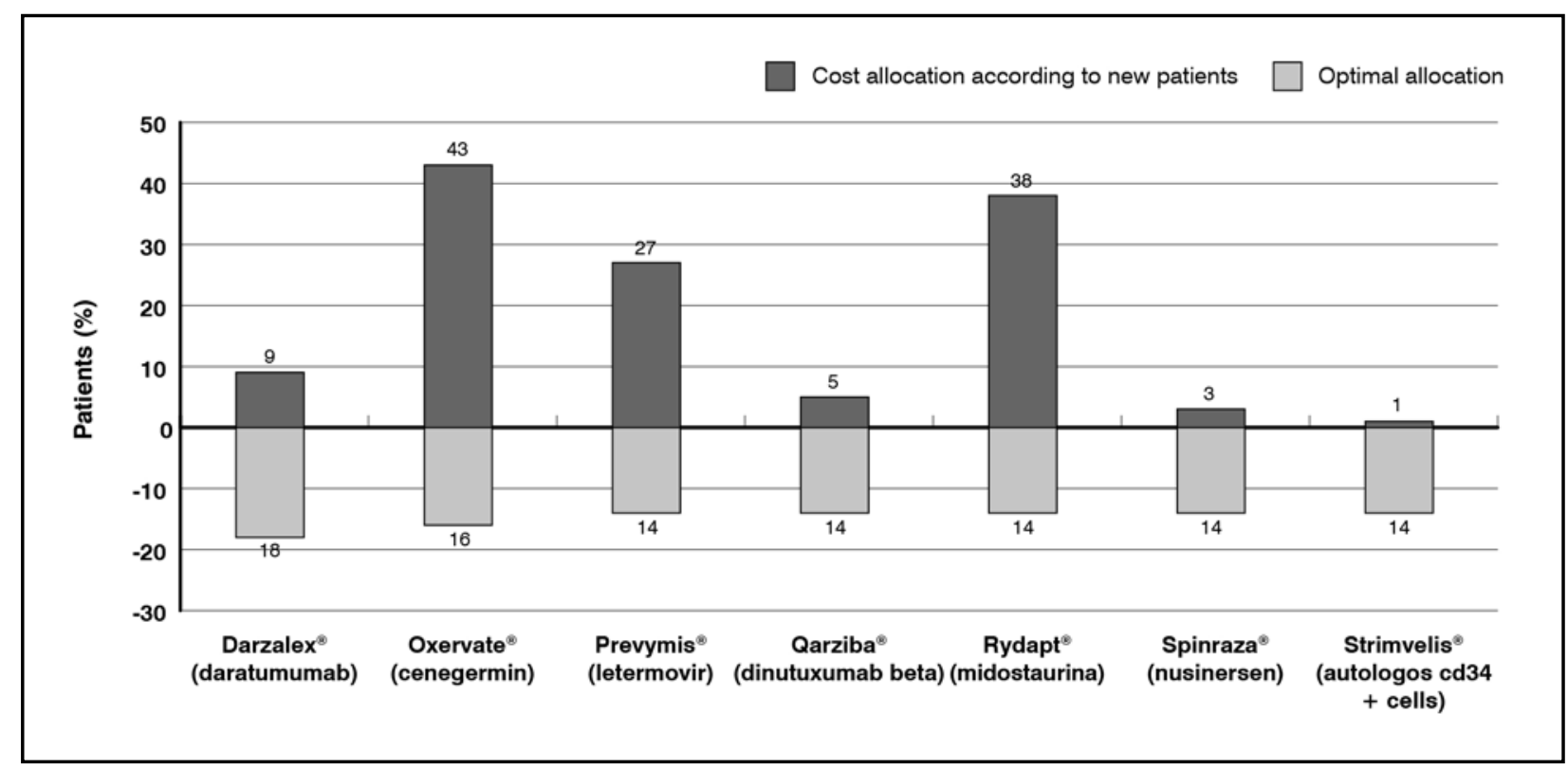

Figure 3. Percentage of new patients potentially treated without impact on NHS due to ATB savings (comparison between allocation proportional to patients and optimal allocation)

grows, from 50\% (current market 2019-2020) to 67\% (future market 2021-2022), produces an increasing trend in the annual savings from about $€ 96$ million in 2019 up to $€ 161$ million in 2022. In line with the AIFA position, this favorable impact on NHS expenditures could be directed to fund innovation, in particular to fund more expensive therapeutic areas, such as orphan drugs gained innovative status.

Our estimate may be too conservative since the biosimilar market is rapidly evolving, both due to increase in biosimilars price discounting and biosimilars uptake; this evolution could lead to greater savings.

The cost analysis by Mulcahy et al. [50] for US estimated that the total biosimilar market (including all available biologic classes) is expected to save approximately $\$ 44$ billion from 2014 to 2024; this savings is due mainly to ATB that account for $21 \%$ of the estimated savings.

Jha et al. [51] estimated the impact of Remsima ${ }^{\circledR}$ for the treatment of autoimmune diseases in five European Countries (Germany, UK, Italy, The Netherlands and Belgium). Under the assumption that the list price of Remsima ${ }^{\circledR}$ might be between $10 \%$ and $30 \%$ lower than the current list price of Remicade ${ }^{\circledR}$, ATB uptake resulted to be associated with considerable drug 
cost savings for the healthcare payer for all countries; in Italy the savings ranged between $€$ 4.6 to $€ 13.8$ Million during the first year after launch.

ATB savings could be used to fund other therapeutic areas. In this analysis, such savings was converted in new patients potentially treated without impact on NHS. Orphan drugs were chosen since the correspondent disease costs are significantly high; according to epidemiology and drugs posology, this impact is estimated in about 740 million per year (Table VI). The annual savings due to ATB uptake could finance $17.4 \%$ of this cost; depending on the decision of the policy makers, favoring equal access across diseases, or rather assigning freed resources proportionally to their incidence in the population, this corresponds to about 2,6004,800 new patients affected by orphan diseases treated with innovative drugs, without increasing overall NHS expenditures.

\section{CONCLUSION}

The introduction of biosimilars in a range of rheumatic, dermatological and inflammatory bowel disease can be an opportunity to increase patient access to innovative treatments. Potential savings due to biosimilars uptake could lead to a re-allocation of economic resources to fund innovative therapies.

\section{Funding}

This study and the article were funded by Biogen Italy. Biogen reviewed and provided feedback on the paper to the authors.

\section{Conflicts of interest}

LP is co-owner and employee of AdRes, which has received project funding from Biogen SRL Italy. MP is employee of AdRes. This study and the article were funded by Biogen Italy.

\section{REFERENCES}

1. EMA. Guideline on "Similar biological medicinal products containing biotechnologyderived proteins as active substance: non-clinical and clinical issues". Committee for Medicinal Products for Human Use (CHMP). EMEA/CHMP/BMWP/42832/2005. 2013. Available at: https://www.ema.europa.eu (last accessed October 2019)

2. Schneider CK, Vleminckx C, Gravanis I, et al. Setting the stage for biosimilar monoclonal antibodies. Nature Biotechnology 2012; 30: 1179-85; https://doi.org/10.1038/nbt.2447

3. Annese V, Vecchi M, on behalf of the Italian Group for the Study of IBD (IG-IBD). Use of biosimilars in inflammatory bowel disease: Statements of the Italian Group for Inflammatory Bowel Disease. Digestive and Liver Disease 2014; 46: 963-8; https://doi.org/10.1016/j. dld.2014.07.019

4. EMA. Guideline on "Similar biological medicinal products containing biotechnologyderived proteins as active substance: quality issues". EMA/CHMP/BWP/247713/2012. 2012. Available at: https://www.ema.europa.eu (last accessed October 2019)

5. Danese S, Gomollon F, the Governing Board and Operational Board of ECCO. ECCO position statement: the use of biosimilar medicines in the treatment of inflammatory bowel disease (IBD). Journal of Crohn's and Colitis 2013; 7: 586-9; https://doi.org/10.1016/j. crohns.2013.03.011

6. AIFA. Secondo Position Paper AIFA sui farmaci biosimilari (27/03/2018). Available at: https://www.aifa.gov.it/position-paper (last accessed October 2019)

7. Flixabi. Summary of Product Characteristics. Available at: http://www.ema.europa.eu/docs/ en_GB/document_library/EPAR___Product_Information/human/004020/WC500208356. $\operatorname{pdf}$ (last accessed October 2019).

8. Inflectra. Summary of Product Characteristics. Available at: http://www.ema.europa.eu/docs/ en_GB/document_library/EPAR___Product_Information/human/002778/WC500151489. $\operatorname{pdf}$ (last accessed October 2019)

9. Remsima. Summary of Product Characteristics. Available at: http://www.ema.europa.eu/docs/en_GB/document_library/EPAR_-_Product_Information/human/002576/ WC500150871.pdf (last accessed October 2019) 
10. Benepali. Summary of Product Characteristics. Available at: http://www.ema.europa. eu/docs/en_GB/document_library/EPAR___Product_Information/human/004007/ WC500200378.pdf (last accessed October 2019)

11. Erelzi. Summary of Product Characteristics. Available at: https://www.ema.europa.eu/en/ documents/product-information/erelzi-epar-product-information_en.pdf (last accessed October 2019)

12. Amgevita. Summary of Product Characteristics. Available at: http://www.ema.europa.eu/docs/it_IT/document_library/EPAR_-_Product_Information/human/004212/ WC500225278.pdf (last accessed October 2019)

13. Imraldi. Summary of Product Characteristics. Available at http://www.ema.europa.eu/docs/ en_GB/document_library/EPAR___Product_Information/human/004279/WC500233920. $\operatorname{pdf}$ (last accessed October 2019)

14. Hyrimoz. Summary of Product Characteristics. Available at: https://www.ema.europa.eu/ en/documents/product-information/hyrimoz-epar-product-information_en.pdf(last accessed October 2019)

15. Hulio. Summary of Product Characteristics. Available at: https://www.ema.europa.eu/ en/documents/product-information/hulio-epar-product-information_en.pdf (last accessed October 2019)

16. Idacio. Summary of Product Characteristics. Available at: https://www.ema.europa.eu/en/ documents/product-information/idacio-epar-product-information_en.pdf (last accessed October 2019)

17. Bellinvia S, Ashraf M, Polosa R. A review article on biosimilar infliximab SB2 in the treatment of rheumatoid arthritis. Immunotherapy 2017; 9: 1133-42; https://doi.org/10.2217/ imt-2017-0068

18. Odinet JS, Dav CE, Cruz JL, et al. The Biosimilar Nocebo Effect? A Systematic Review of Double-Blinded Versus Open-Label Studies. J Manag Care Spec Pharm 2018; 24: 952-9; https://doi.org/10.18553/jmcp.2018.24.10.952

19. McKinnon RA, Cook M, Liauw W, et al. Biosimilarity and Interchangeability: Principles and Evidence: A Systematic Review. BioDrugs 2018; 32: 27-52; https://doi.org/10.1007/ s40259-017-0256-Z

20. Cohen HP, Blauvelt A, Rifkin RM, et al. Switching Reference Medicines to Biosimilars: A Systematic Literature Review of Clinical Outcomes. Drugs 2018; 78: 463-78; https://doi. org/10.1007/s40265-018-0881-y

21. Numan S, Faccin F. Non-medical Switching from Originator Tumor Necrosis Factor Inhibitors to Their Biosimilars: Systematic Review of Randomized Controlled Trials and RealWorld Studies. Adv Ther 2018; 35: 1295-332; https://doi.org/10.1007/s12325-018-0742-9

22. Jacobs I, Petersel D, Shane LG, et al. Monoclonal antibody and fusion protein biosimilars across therapeutic areas: a systematic review of published evidence. BioDrugs 2016; 30: 489-523; https://doi.org/10.1007/s40259-016-0201-6

23. Goll GL, Olsen IG, Jorgensen KK et al. Biosimilar Infliximab (CT-P13) is not inferior to originator infliximab: results from a 52-week randomized switch trial in Norway. Presented at: 2016 ACR/ARHP Annual Meeting. Washington, DC, 11-16 November 2016

24. Glintborg B, Sørensen IJ, Loft AG, et al. A nationwide non-medical switch from originator infliximab to biosimilar CT-P13 in 802 patients with inflammatory arthritis: 1 year clinical outcomes from the DANBIO registry. Ann Rheum Dis 2017; 76: 1426-31; http://doi. org/10.1136/annrheumdis-2016-210742

25. Holroyd C, Parker L, Bennett S, et al. Switching to biosimilar infliximab: real-world data from the Southampton biologic therapies review service. Rheumatology 2016; 55: i60-i61; https://doi.org/10.1093/rheumatology/kew121.003

26. Park W, Yoo DH, Miranda P, et al. Efficacy and safety of switching from reference infliximab to CT-P13 compared with maintenance of CT-P13 in ankylosing spondylitis: 102-week data from the PLANETAS extension study. Ann Rheum Dis 2017; 76: 346-54; https://doi. org/10.1136/annrheumdis-2015-208783 
27. Yoo DH, Prodanovic N, Jaworski J, et al. Efficacy and safety of CT-P13 (biosimilar infliximab) in patients with rheumatoid arthritis: comparison between switching from reference infliximab to CT-P13 and continuing CT-P13 in the PLANETRA extension study. Ann Rheum Dis 2017; 76: 355-63; https://doi.org/10.1136/annrheumdis-2015-208786

28. Emery P, Vencovsky' J, Sylwestrzak A, et al. Long term safety and efficacy of SB4 (etanercept biosimilar) in patients with rheumatoid arthritis: comparison between continuing SN4 and switching from etanercept reference product to SB4. Ann Rheum Dis 2016; 75: 236; https://doi.org/10.1136/annrheumdis-2016-eular.3137

29. Glintborg B, Loft AG, Omerovic E, et al. To switch or not to switch: results of a nationwide guideline of mandatory switching from originator to biosimilar etanercept. One-year treatment outcomes in 2061 patients with inflammatory arthritis from the DANBIO registry. Ann Rheum Dis. 2019;78(2):192-200; https://doi.org/10.1136/annrheumdis-2018-213474

30. Inotai A, Prins CPJ, Csanádi M, et al. Is there a reason for concern or is it just hype? - A systematic literature review of the clinical consequences of switching from originator biologics to biosimilars. Expert Opin Biol Ther 2017; 17: 915-26; https://doi.org/10.1080 $/ 14712598.2017 .1341486$

31. The IQVIA Institute. Advancing Biosimilar Sustainability in Europe - A Multi-Stakeholder Assessment. Institute Report, 2018. Available at: https://www.iqvia.com/institute/reports/ advancing-biosimilar-sustainability-in-europe\#reportcharts (last accessed October 2019)

32. IMS anti-TNF- $\alpha$ sell-in units - Biogen data on file

33. Informatore Farmaceutico on-line. Available at: http://www.codifa.it/ (last accessed October 2019)

34. SoReSa - Amministrazione Trasparente Regione Campania. Available at: https://www. soresa.it/amministrazionetrasparente/bandi-di-gara-e-contratti (last accessed October 2019)

35. AIFA. Determina 12 settembre 2017 - Criteri per la classificazione dei farmaci innovativi e dei farmaci oncologici innovativi ai sensi dell'articolo 1, comma 402 della legge 11 dicembre 2016, n. 232. Available at: https:/www.aifa.gov.it/farmaci-innovativi (last accessed October 2019)

36. AIFA. Elenco dei farmaci innovativi ai sensi dell'articolo 10, comma 2, Legge 8 novembre 2012, n. 189, come definito dall'art. 1 comma 1 e 2 dell'accordo Stato Regioni del 18 novembre 2010. Available at: https://www.aifa.gov.it/farmaci-innovativi (last accessed October 2019)

37. De Portu S, Fanin R, Patriarca F, et al. The burden of multiple myeloma: assessment on occurrence, outcomes and cost using a retrospective longitudinal study based on administrative claims database. IJPH 2011; 8: 325-30; https://doi.org/10.2427/5678

38. Dimopoulos MA, Oriol A, Nahi H, et al. Daratumumab, Lenalidomide, and Dexamethasone for Multiple Myeloma. N Engl J Med 2016; 375: 1319-31; https://oi.org/10.1056/ NEJMoa1607751

39. Palumbo A, Chanan-Khan A, Weisel K, et al. Daratumumab, Bortezomib, and Dexamethasone for Multiple Myeloma. N Engl J Med 2016; 375: 754-66; https://doi.org/10.1056/ NEJMoa1606038

40. Sacchetti M, Lambiase A. Diagnosis and management of neurotrophic keratitis. Clin Ophthalmol 2014; 8: 571-79; https://doi.org/10.2147/OPTH.S45921

41. Versura P, Giannaccare G, Pellegrini M, et al. Neurotrophic keratitis: current challenges and future prospects. Eye Brain 2018; 10: 37-45; https://doi.org/10.2147/EB.S117261

42. Passweg JR, Baldomero H, Bader P, et al. Hematopoietic stem cell transplantation in Europe 2014: more than 40000 transplants annually. Bone Marrow Transplant 2016; 51: 786-92; https://doi.org/10.1038/bmt.2016.20

43. Malerba L, Tommasini I, Isidori T, et al. Monitoraggio e terapia delle riattivazioni del citomegalovirus in seguito a trapianto autologo di cellule staminali emopoietiche: studio prospettico su 92 pazienti. GIFAC 2012; 26: 398-407; https://doi.org/10.1721/1213.13427

44. Associazione Italiana Ematologia Oncologia Pediatrica (AIEOP). Epidemiology of Neuroblastoma in Italy. Available at: https://www.aieop.org/web/famiglie/schede-malattia/ 
neuroblastoma/ (last accessed October 2019)

45. Cacciari E, Milani S, Balsamo A, et al. Italian cross-sectional growth charts for height, weight and BMI (2 to 20 yr). J Endocrinol Invest 2006; 29: 581-93; https://doi.org/10.1007/ BF03344156

46. Heck JE, Ritz B, Hung RJ, et al. The epidemiology of neuroblastoma: a review. Paediatr Perinat Epidemiol 2009; 23: 125-43; https://doi.org/10.1111/j.1365-3016.2008.00983.x

47. AIRTUM. Rare Haematological Diseases. Rapporto AIRTUM 2015. Available at: https:// www.registri-tumori.it/PDF/AIRTUM2016/TUMORIRARI/AIRTUM_RARI_S014_haema.pdf (last accessed October 2019)

48. Stone RM, Mandrekar SJ, Sanford BL, et al. Midostaurin plus Chemotherapy for Acute Myeloid Leukemia with a FLT3 Mutation. N Engl J Med 2017; 377: 454-64; https://doi. org/10.1056/NEJMoa1614359

49. Sugarman EA, Nagan N, Zhu H, et al. Pan-ethnic carrier screening and prenatal diagnosis for spinal muscular atrophy: clinical laboratory analysis of $>72,400$ specimens. Eur J Hum Genet 2012; 20: 27-32; https://doi.org/10.1038/ejhg.2011.134

50. Mulcahy A, Predmore Z, Mattke S. The cost savings potential of biosimilar drugs in the United States. Rand Corporation. 2014. Available at: https:/www.rand.org/content/dam/ rand/pubs/perspectives/PE100/PE127/RAND_PE127.pdf (last accessed October 2019)

51. Jha A, Upton A, Dunlop WCN, et al. The Budget Impact of Biosimilar Infliximab (Remsi$\mathrm{ma}^{\circledR}$ ) for the Treatment of Autoimmune Diseases in Five European Countries. Adv Ther 2015; 32: 742-56; https://doi.org/10.1007/s12325-015-0233-1 